\title{
Impacts of Hill Torrents' Management on Socio-Economic Conditions of Arid Land Farmers: a Case Study of Tehsil D.G. Khan
}

\section{Muhammad Adeel Kamran ${ }^{1}$, Tahira Shamshad ${ }^{2}$}

${ }^{1}$ District Literacy Officer, Literacy and Non Formal Basic Education Department, Dera Ghazi Khan, Pakistan ${ }^{2}$ Lecturer, Department of Sociology, Ghazi University, Dera Ghazi Khan, Pakistan

Volume 2, Number 1/2015

DOI prefix: 10.18034/ajhal

Licensed:

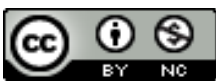

Source of Support: Nil

Conflict of Interest: None Declared

Email for correspondence: adeelkhosa@gmail.com

\section{ABSTRACT}

The study conducted in arid areas of Dera Ghazi Khan occasionally affected by hill torrents (Suri-Lund, Vidore, Sakhi-Sarwar, Mithawan) coming from Koh-e-Suleman range. The study found that hill torrent water is used for agriculture, domestic and livestock. The management of this water significantly affects on income, crop yield, soil fertility, health conditions and living standard of farmers. The local cost effective methods to store this water include wah, dubba and bundh but most of water is wasted as they are insufficient. The water distribution mechanism fosters cooperation and helps to form new relations with cofarmers. The study suggested that government and NGOs should help people to construct concrete diversions, bundhs, ponds and dams to manage hill torrent water.

Key Words: Hill torrents management, catchment area, water distribution mechanism, social relations

\section{INTRODUCTION}

The mountainous landscape of area causes speedy water run-off from hills and deep storage in soil providing enough moisture to crop in dry seasons (Mehrai et al., 2005). Rod Kohi irrigation (Hill Torrent-Spate) is a system in which run-off water from flash floods and mountain springs is diverted by constructing small dams (bunds), embankments and channel. It is used for irrigating fields located in the valley. It provides water for local farming system, forestry and rangelands as well as drinking water supplies-either directly or through recharge of shallow aquifers. The water coming from hills through natural water channels is called Rods (FAO, 2010). Spate irrigation is called Rod Kohi in Punjab and NWFP provinces, Sailaba in Balochistan and nai in Sindh and Punjab (Ahmed, 2000). It is a unique system of water management particularly in areas where heavy rainfall on mountains generates flood (Mehrai et al., 2005).

Rod kohi irrigation carries out a system of water distribution (warabandi), which was institutionalized by the British government before independence of Pakistan. Since that time, the government of Pakistan is following the same rules regarding rights of shareholders on 
hill torrent water. The warabandi system is maintained by recording the irrigation rights of farmers into a register specified for each rod kohi. These hand-written registers are still in use as legal document. But on the ground, there is no implementation of warabandi system. The farmers themselves have developed rules for water allocation and there is no interference of the government to this system. According to the existing warabandi system, the farmer who is at the upstream irrigates his land first and stores water in his bund as much as he can. This practice tends to allow farmers to over irrigate and cause wastage of water. When the upstream farmer has satisfied his demand of water, he diverts water to the next farmer's land. The diversion of water to the next farmers depends upon their rights (Ahmad and Choudhry, 2005). At the head, the problem is too much water, whereas tail reaches receive water only if the quantity is in excess of the upper reaches. Some of the tail reaches receive water once in three years (Ikram et al., 2001). Moreover, the upstream farmers usually do not follow the rules in diverting water to the next right. Instead, they divert water to their friends and relatives who even do not have right of irrigation on that water channel. This is mostly done by powerful land owners (Ahmad and Choudhry, 2005). The centuries old system is working with some mutually understood rules. The resource settings and geographic areas are divided into upland and lowland systems. The upland system stands for distribution mechanisms of hill torrent water on mountains and lowland means distribution mechanism beneath the mountains in the valley. These two systems are different from each other to some extent in terms of operational rules.

Irrigation rights: For both lowland and upland systems, the irrigation rights are fixed to the "Haqooq lands" (land having right of irrigation). The logic of getting status of haqooq land is stated to the contribution in communal systems development centuries back. The non-haqooq lands (land not having right of irrigation) in the command area are one which were either uncultivable previously, or the owners did not participate in development work at the initial stages.

Transfer of rights: For lowland system, the water transfer rights are bound with the land and are transferred with sale or purchase of specific land while in upland system the land and water has different legal transfer rights.

Work Distribution: For both lowland and upland systems, the work is determined based on kamara system i.e. estimated on the number of oxen needed to cultivate haqooq land or labor and money contribution proportionate to water haqooq.

Water Distribution system: For both lowland and upland systems, Saropa-paina (head to tail) system is usually followed with the head end have first right for irrigation. The irrigation turn in upland is determined through "lottery". The non-perennial systems mostly irrigate as much as they need while perennial system follow fixed time slots.

Land-water relationship: For lowland system, every share holder can only irrigate specific haqooq lands based on flexibility in quantity of irrigation. The land cannot be replaced with other land without irrigation rights and without collective permission to do so while, for upland system, the land and water have separate transfer rights in revenue records. Some member can sell their water share if the land is eroded, and others with reclaimed land or non-haqooq land in the system can buy this right.

Community's response to distribute water: For lowland system, the tail end farmer can break diversion structure at main water course if the head end farmer's water is going to non-haqooq lands or going waste out of field and for upland system, the fixed sequence of irrigation is known to all members and maimar (institution which ensure the implementation of rules). The farmers with next turn can divert water to his fields at fixed time. 
Codification of rules and legal recognition: For lowland system, all haqooqs are codified since British time (having thumb impressions of all land owners) with details about haqooq lands and work contributions while, for upland system, rules are not codified just well known and recognized by community members and tribal elders.

Enforcement: For lowland system, the Rod-kohi (spate) department is to help enforce rules if farmers and Maimar themselves cannot resolve any problem while for upland system, there is no specific government agency for enforcement of rules. The tribal elders constituting Jirga mediate if conflicts are not resolved by the irrigators and Maimar (Kamran and Shivakoti, 2009).

\section{Objectives:}

- To assess the role of hill torrents management in improving living standard of farmers.

- To investigate how hill torrents management influence social relationships of farmers.

- To find out the extent to which local methods of hill torrents management are cost effective for farmers.

\section{REVIEW OF LITERATURE}

Hill torrent irrigation is a centuries old system being practiced in hilly areas of Pakistan. This system has great potential for agriculture if managed properly. Some studies account their role for agriculture.

Mumtaz (1989) concluded that crop production in arid areas is of subsistence level due to uncertain source of water. Farmers have been using the flood water for irrigation by diverting into channels for decades but now due to physical, technical, financial and social constraints, this has become dysfunctional. The major crops grown during Rabi are wheat, barley and oilseed while millets, sorghum, mung beans are the summer crops. The existing Rod Kohi irrigation practices are not up-to-date. Poor flood water management and improper use of other essential inputs causes low crop production in the area.

Bhatti (1998) stated that the water of hill torrents gushes down to the valley and causes serious flooding in lowlands. This water is diverted for irrigation through weirs or temporary diversion structures and earthen embankments called bund. The water is distributed through head-to-tail rule, and this may cause damage to downstream infrastructure. However, this system has great potential for improvement and if properly managed, could certainly results in more irrigation, greater production, recharged groundwater and less damage to downstream infrastructure.

SUNGI Development Foundation and DAMAAN Development Organization (2000) reported that hill torrents have specific courses to follow bringing huge quantities of speedy and muddy water with them. The utilization of this water depends on the ability of the people to manage it by blocking it intermittently and temporarily to fill their fields, which are bound by a $2 / 3$ feet high earthen bund. The fields get saturated with this water have a layer of silt and once sown in, can produce a good crop without any further irrigation. For years, people have made collective efforts at starting points of these torrents to consolidate their lands along the water routes but with intervention of new agricultural system social relations are weakening.

Bakhash (2004) conducted a study at the Mithawan Hill Torrent in Dera Ghazi Khan and Rajan pur. Rod Kohi irrigation system needs to be promoted because it is not only low cost, environment-friendly and people oriented but also conserves land and water. Despite its 
enormous potential, the system has been the most neglected and under developed because of low investment, poor farmers, lack of improved water management practices and integrated scientific study. Moreover, nonexistence of control structure, unpredictability, short duration and high intensity of rainfall and runoff makes the situation worsen.

Nawaz and Han (2008) stated that $65 \%$ of the total agricultural area of Pakistan is rain-fed, and traditional method of Rod Kohi is common for irrigation. In these areas the major constraint is the use of flood flow which is highly variable in quantity and distribution, both in time and space. The agriculture in these areas is totally dependent on rainfall, although affected by flood with rainfall but most of the times remain without water. The major problem is the unavailability of any kind of storage and modernized engineering structures, though a lot of efforts and money were spent in order to control the torrents flow drawback of the previous studies.

United Nations Development Program (2010) reported that the major part of hill-torrent water goes wasted because of insufficient hill torrent management facilities. Proper management of hill torrents can significantly enhance agricultural production, ensure food security and improve livelihoods of people living in Rod Kohi areas. Rod Kohi Irrigation System should be encouraged since it is not only low cost, environmentally sustainable, and people oriented, but also it helps in preventing land degradation and desertification. Despite its potential, this system has remained the most neglected and underdeveloped irrigation system in Pakistan mainly because of low Government priority, poor resources of Rod Kohi farmers, ignorance of farmers to improve irrigation practices, unpredictable torrential rains, excessively high flows, non-existence of control structures, and lack of scientific investigations for the improvement of this traditional irrigation system.

\section{Methodology}

The study was conducted in arid areas of Tehsil Dera Ghazi Khan, which are occasionally affected by hill torrents coming from Koh-e-Suleman range. There are four major hill torrents in Tehsil Dera Ghazi Khan named as:

\section{Suri Lund 2. Vidore 3. Sakhi Sarwar 4. Mithawan}

The universe of study consisted of all the farmers who are affected by these hill torrents and are dependent on water of these hill torrents for agriculture and domestic use in Tehsil Dera Ghazi Khan in 2011. The researcher used quota sampling technique. The population was divided into four categories according to the catchment area of hill torrents and sixty-five respondents were selected from each category. So the sample size for this study was $(65 \times 4=260)$. The respondents were interviewed by asking structured and semi-structured questions about the effects of hill torrents on their standard of living, health and social relations.

The validity and reliability of the research tool were checked through pre-testing by interviewing forty respondents. After pre-testing, two questions had been added, two questions were restated and in one question, response category was changed. The data were analyzed by percentage and chi-square.

\section{Results AND Discussion}

According to results, the people involved in agriculture were mostly above the age of forty years, and their income was below ten thousand rupees. The young ones were less involved in agriculture because it was not a reliable source of income in these areas due to 
uncertainty of water availability. This avoided people to cultivate the cash crop and invest in agriculture. Moreover, majority of the respondents were illiterate or educated less than primary level. The dominant family system was joint or extended family in which the couple lives with their children and some close relatives of husband or wife such as parents and siblings. Mostly people did not have large landholdings because the water was not available round the year and water table was also very low. That is why most of the land in this area remained barren and uncultivated. Most cultivated crops of the area included millet (Bajra), pakmillet (Jawar), chick-pea and barley because it required minimum water. Livestock was an important factor of socio-economic condition of farmers. In rural areas livestock was used commonly as source of earning, especially in arid land where uncertainty of water availability was common for crops, so the people of arid land mostly depend upon the livestock. The hill torrents used to come more than two times in a year. This means that whenever the rainfall is heavy on the mountains, the water gushes down and comes toward the valley. This water is diverted into water channels called Wah by making diversion structures called Gandh. The water channel is then diverted to Bundh that is the field with raised borders to store more water. In Bundh, the water is stored for the longer time to conserve moisture for subsequent crops. The location from where the water enters into the Bundh is called Moonh. It is designed in a way that water enters into the field easily under gravity flow and is usually at higher level side. Dubba is a water pond where water is naturally stored in down lands. The native people stored the water of hill torrents by using these indigenous methods.

The different methods used to store hill torrent water were usually cost effective as shown in figure 1 because these methods involved the community participation in terms of resources and their efforts to store water. The indigenous resources and tools were used to make Wah or Bundh. This stored water was then used for agriculture, livestock and domestic use and in most of the areas, this is the only source of water. The water was distributed among farmers by "Riwajat-e-Abpashi" (irrigation customs or Haqooq-eAbpashi) codified in British rule and the local known customs. In agriculture, the water was mostly distributed by warabandi system as shown in figure 2 in which every irrigator gets the share of water proportionate to his share in labor work. The principle of Saropapaina (head to tail) is followed while constructing all diversion structures. These rules and customs are well defined and readily followed by the farmers. If there is any violation of the rules by any member, it is dealt with the heavier penalty. As the population throughout the system is homogeneous, community pressure and loss of reputation on being caught are found to be the major penalty for users followed by more strict economic sanctions of fixed amount of fine and one season ban on irrigation or some additional work for violating a rule. For domestic and livestock use, mostly the distribution of water was need based while in some areas both the systems were used for mixed purposes.

The management of hill torrents water has significant effects on standard of living of farmers. These effects were measured in terms of income; saving, health conditions, crop yield, soil fertility, landholding and opportunity to cultivate round the year. The results given in figure 3 indicated that effects of hill torrents management on income, saving, crop yield per acre and soil fertility were more significant because the hill torrent water was comparatively cheap and having more nutrients. On the other hand, farmers were unable to store and manage all the water so effects on health conditions, landholding and opportunity to cultivate round the year were less significant. 


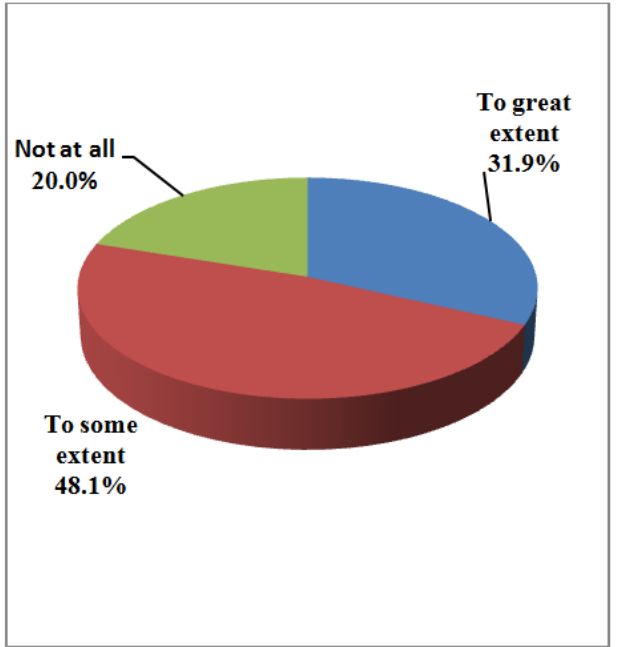

Figure 1: Methods are cost effective

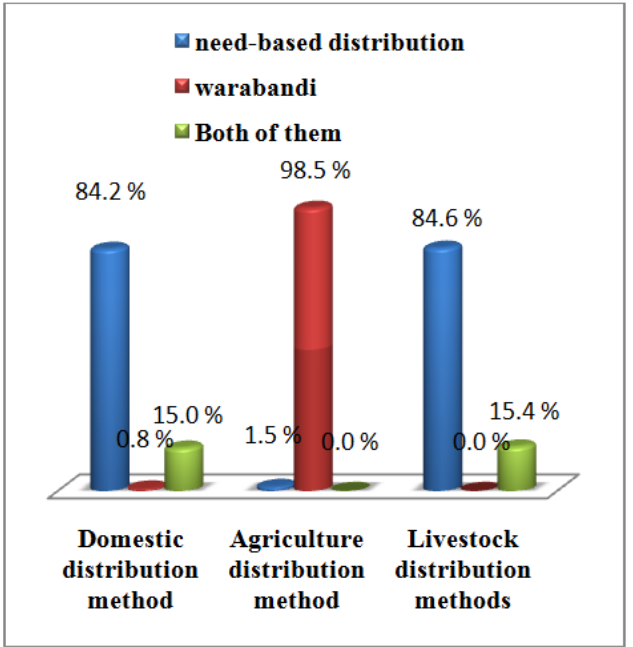

Figure 2: Water Distribution Mechanisms

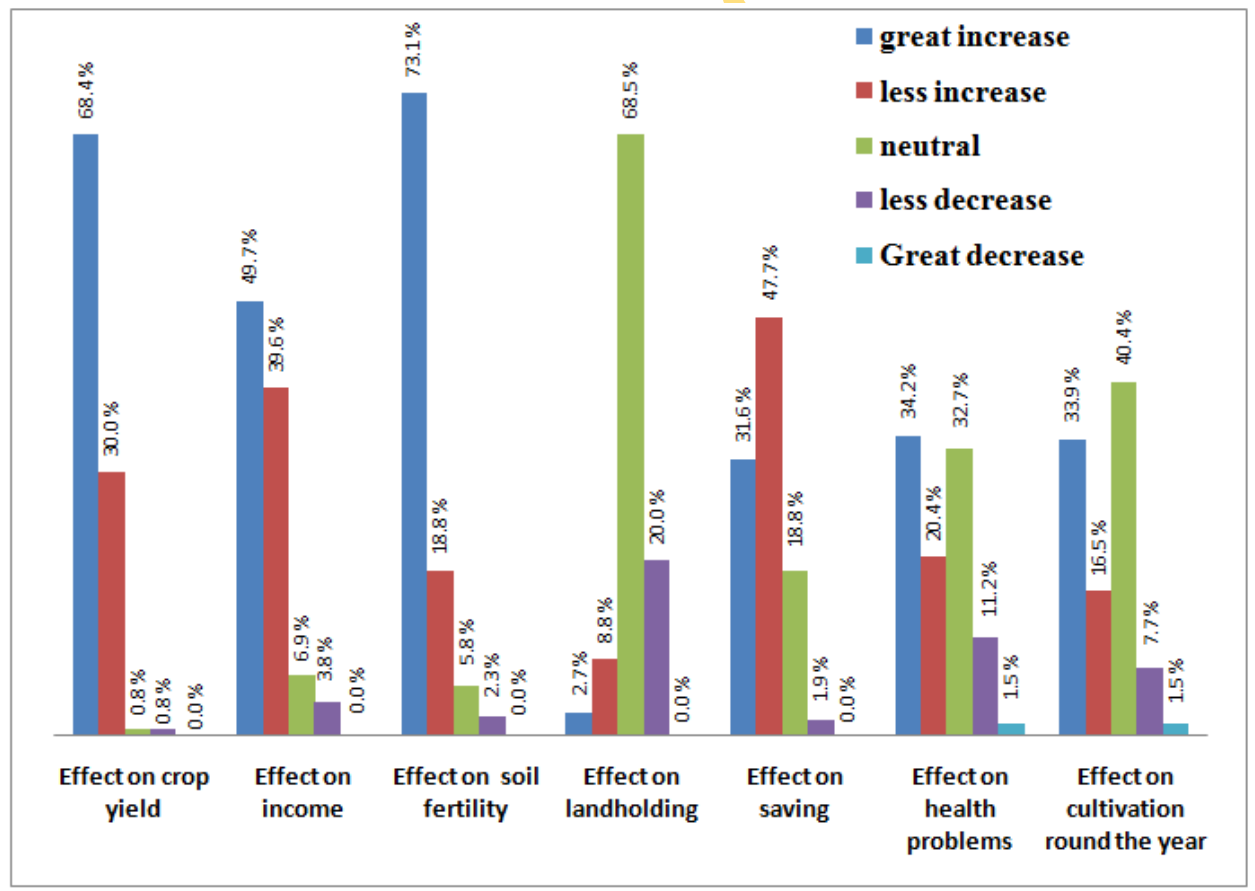

Figure 3: Effects on standard of living

The management of hill torrent was totally a collaborative work at indigenous level, so it has very significant effects on the social relations. These effects were measured in terms of effects on primary relatives, secondary relatives and neighbors (banna Sharik). The results in figure 4 indicated that effects of hill torrents management on primary and secondary relatives (blood relatives) were good and positive because water distribution mechanism fostered cooperation among farmers while relations with neighbors (banna Sharik) might be subject to competition for water, so these relations were not so good. Moreover, water 
distribution mechanism in hill torrent irrigation also helped to form new relations with cofarmers. Further, hill torrents management process is facilitated by government and nongovernment organizations working in the area but the involvement of government is greater than NGOs. Moreover, people expect from government to take initiatives in order to construct dams, concrete diversions, ponds and bundhs.

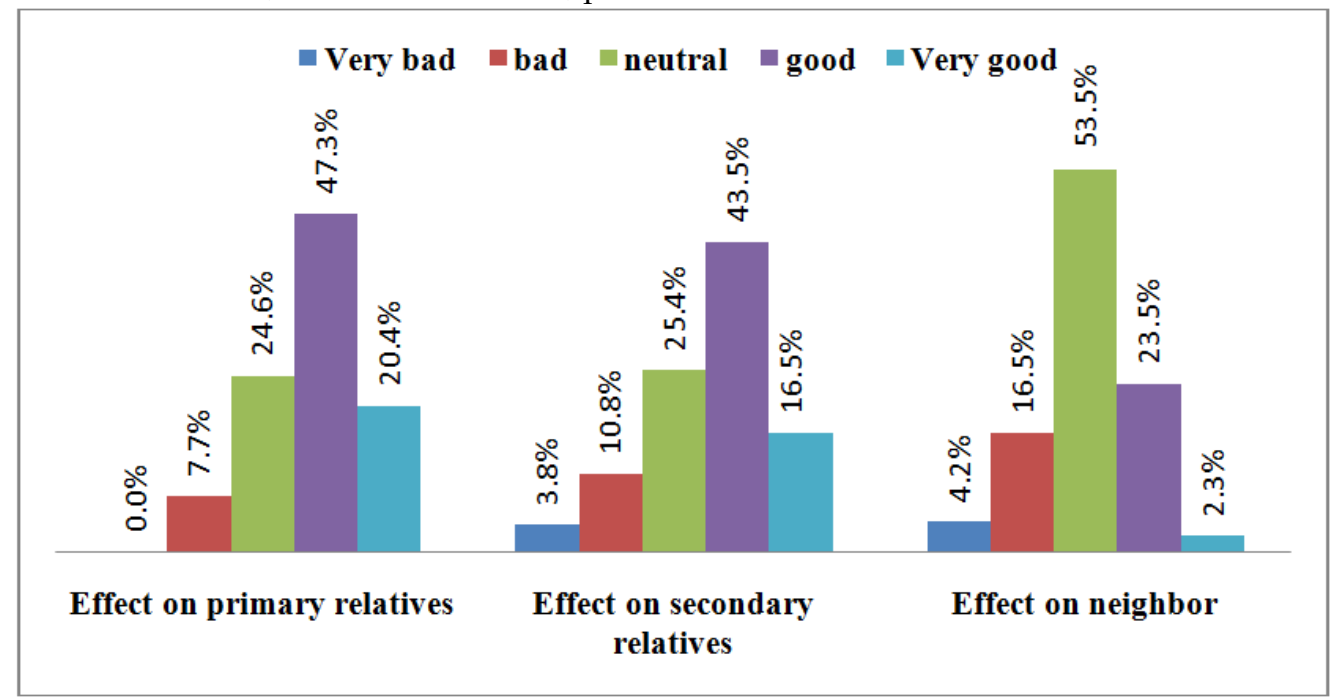

Figure 4: Effects on Social Relations

The results of chi-square tests showed that hill torrents management is directly associated with income of farmers. Similarly, hill torrents management leads to cooperation among farmers and also provides opportunities to form new social relations with farmers.

\section{CONCLUSION}

Hill Torrent is a unique system of irrigation, as being practiced since centuries in the regions of Derajat, i.e. the areas of Dera Ismail Khan and Dera Ghazi Khan. Hill Torrent is locally named as Rod-Kohi, Rod means a stream or water channel and Kohi is from the word Koh i.e. hill or mountain as such it literally means; "water from hill torrents". The native people store this water by using indigenous methods of wah, bundh and dubba. This water is used for agriculture, livestock and domestic purposes. The water is distributed among farmers by "Riwajat-e-Abpashi" (irrigation customs or Haqooq-e-Abpashi) codified in British rule and the local known customs. These rules and customs are well defined and readily followed by the farmers. Any violation of the rules is sanctioned by community pressure and loss of reputation. Other strict economic sanctions of fixed amount of fine and one season ban on irrigation or some additional work for violating a rule. This is the only source of water in the area as water table here is very low. The land is very fertile but remained barren due to uncertainty of water. So if this water is properly managed, it could improve the living conditions of farmers not only by providing them sufficient water for agriculture and other uses but also protecting them from destructions of Rod Kohi flood. For this, small dams, diversions and ponds should be constructed through public and private partnership. 


\section{REFERENCES}

Ahmad, M. and Choudhry, M.R. (2005). Farmers' Irrigation Practices Under rod Kohi Irrigation System. Pakistan Journal of Water Resources, vol.9(1)January-June.

Ahmed, S. (2000). Indigenous water harvesting systems in Pakistan. Water Resources Research Institute (WRRI), National Agricultural Research Centre (NARC), Islamabad, Pakistan.

Bakhsh, Allah. (2004). Rod Kohi irrigation System in Southern Punjab. Department of irrigation and Drainage, university of agriculture, Faisalabad 38040 Pakistan

Bhatti, Khawer Ali: Randhawa, Abdul Ghan, et al,. (1998). Master feasibility Studies for flood management of Hill Torrents of Pakistan. Islamabad: NESPAK and the federal Flood commission of Pakistan.

FAO. (2010). Guidelines on spate irrigation. FAO irrigation and drainage paper 65

Ikram, Noaman, javaid, Ahmed, Nasim, Shah, Sadiq, Nizamani, Somroo. (2001). Rod-Kohi system development and management in Pakistan-A national Project. Water Resources Research Institute National Agricultural Research Center, Islamabad.

Kamran, M. Asif and Shivakoti, G. Prasad. (2009). Design Principles and robustness of Spate community managed irrigation systems in the Punjab, Pakistan.

Lashari NA and Mohyuddin DA. 2012. Economic Activities among Barra Community in Sindh, Pakistan: A Case study of Matli Town, District Badin ABC Journal of Advanced Research, 1, 23-31.

Mehrai, A. Steenbergen, F., and Schulz, B. (2005). Water rights and rules and management in spate irrigation systems in Eriteria, Yemen and Pakistan. Proceedings of the International Water Management Institute Workshop, Johannesburg, South Africa.

Mehrai, A., Schulz, B., and Depeweg, H. (2005). Hydraulic performance evaluation of the spate irrigation systems in Eriteria. Irrigation and Drainage 54.4:1-14.

Mumtaz, A (1989). Keynote Address, In: BARD Rod kohi Agricultural Problems and Prospects Symposium, Nov. 27-29 1989, Islamabad, Pakistan Agriculture Research Council, 2-9.

Nawaz M., and Han M. (2008) Hill Torrents Management for Increasing Agricultural Activity in Pakistan [online]. Available at http:/ / www.spate-irrigation.org.

SUNGI Development Foundation and DAMAAN Development Organization. (2000). Chasma Right Bank Irrigation Project (CRBIP): A Survey Report.

United Nations Development Program. (2010). Consultant - "Climate Change Impacts on Rod Kohi (Hill Torrent)". Islamabad.

This article is is licensed under a Creative Commons Attribution-NonCommercial 4.0 International License. Attribution-NonCommercial (CC BY-NC) license lets others remix, tweak, and build upon work non-commercially, and although the new works must also acknowledge \& be non-commercial.

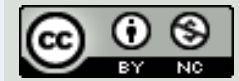

How to Cite: Kamran MA and Shamshad T. 2014. Impacts of Hill Torrents' Management on Socio-Economic Conditions of Arid Land Farmers: a Case Study of Tehsil D.G. Khan Asian Journal of Humanity, Art and Literature, 2, 29-36. 


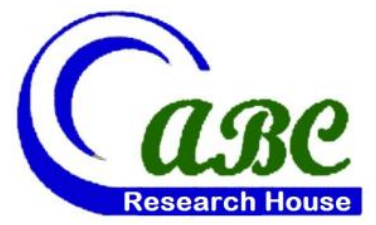

- Off Pantai Dalam, Kuala Lampur, Malaysia

- Road \# 4, Shyamoli, Dhaka-1207, Bangladesh

- 3900 Woodhue Place, Alexandria, VA 22309, USA

www.abcreorg.weebly.com / www.abcjournals.net

Asian Business Consortium (ABC) is a multi-disciplinary research, training, publishing, digital library supporting and service house. Though founded in 2010 as the Business and Computing organization of Asia, it was reconstituted as the ABC in 2011. It has been working for creating and nurturing talents in USA, Malaysia and Bangladesh since its inception. The objectives of consortium are solely centered round the welfare and humane attitude of the founders who enthusiastically took up this noble cause and materialized it with a view to promote research and educational activities for the encouragement of scholars to develop their knowledge, to publish their analysis oriented scientific researches in international Journals, books, the task of organizing workshops, seminars, conferences, training, personality development programs and allied services.

In addition to research activities, $A B C$ provides a good number of scholarships to the poor and meritorious students at various levels of education throughout the world. It plays an important role in the field of research by funding research projects and publishing the research papers. This consortium will unquestionably become the mouth-piece of the dark horses and unacknowledged scholar whose endowed and commendable contributions shall be provided an outlet keeping in mind the greater good of the larger society of the world.

$\mathrm{ABC}$ runs the following international referred journals for creating a platform to share the thoughts of professionals, scholars and academicians throughout the world.

\section{ABC Publications (ABC Journals)}

- Asian Accounting and Auditing Advancement (4A Journal)

- Asian Business Review (ABR)

- Asian Journal of Applied Sciences and Engineering (AJASE)

- Global Disclosure of Economics and Business (GDEB)

- $\quad$ ABC Journal of Advanced Research (ABC-JAR)

- International Journal of Reciprocal Symmetry and Theoretical Physics (IJRSTP)

- American Journal of Trade and Policy (AJTP)

- Asian Journal of Humanity, Art and Literature (AJHAL)

- Malaysian Journal of Medical and Biological Research (MJMBR)

- Asia Pacific Journal of Energy and Environment (APJEE)

- $\quad$ Engineering International (EI)

- $\quad$ ABC Research Alert (Online)

Each journal home page provides specific information for potential authors and subscribers. Open access policy, the quick review process, rich editorial boards and quality publications have already made $A B C$ Journals unique. ABC Journals are published under the direct supervisions of renowned academicians of the world.

Collaboration in Conference: $A B C$ considers high-quality conference papers for publication. Please contact us for detailed information.

Collaboration in Publishing: If you like to start writing a book, propose a new journal or advertise in $\mathrm{ABC}$ journals, please feel free to contact us. 